\title{
Mud volcanoes in the Khar Argalantyn Nuruu, NW Gobi Altay, Mongolia as manifestation of recent seismic activity
}

\author{
Lenka RUKAVIČKOVÁ1,*, Pavel HANŽL² \\ ${ }^{1}$ Czech Geological Survey, Geologická 6, 15200 Prague 5, Czech Republic; lenka.rukavickova@geology.cz \\ ${ }^{2}$ Czech Geological Survey, Leitnerova 22, 60200 Brno, Czech Republic \\ * Corresponding author
}

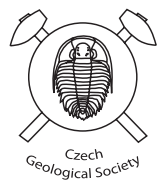

A group of mud volcanoes was discovered in the NW part of the Gobi Altay on a northern foothill of the Khar Argalantyn Nuruu Mts. Several mud cones and mud mounds with elevation up to $0.8 \mathrm{~m}$, as well as pools with muddy water and mud outflows were encountered. Jurassic to Quaternary sedimentary successions provide the source for the mud volcanoes. Jurassic sediments cover transgressively Permian volcanics forming several confined aquifers within a subsided, triangle shaped block. The aquifers are saturated with groundwater derived from the Khar Argalantyn Nuruu Mts. To the northwest and to the east this block is bordered by sealed faults. The significant recent seismic activity occurring in the area is related to Cenozoic faults as a response to the collision of the Indian and Eurasian continental plates. The mud volcanoes originated probably as a result of the Gobi-Altay Earthquake in 1957. The earthquake of magnitude 8.3 generated new fractures or reactivated existing fractures. The impulse of the earthquake exceeding the thixotropy of fine-grained sediments initiated the rise of the mud volcanoes. The recent equilibrium of pressure conditions in the area is labile. Earthquakes or increase in piezometric level of groundwater caused by heavy rainfalls can trigger activity of the mud volcanoes. A high content of smectites in sediments and loss of binding of clay particles due to soluble salts support mud outflows during such starting events.

Keywords: mud volcano, liquefaction, thixotropy, earthquake, Gobi Altay, Mongolia

Received: 18 March 2008; accepted 4 June 2008; handling editor: S. Vrána

\section{Introduction}

\subsection{Origin of mud volcanoes}

A mud volcano is a positive topographic feature constructed mainly of mud and other sedimentary constituents, which periodically or continuously vents liquid mud, including water, oil and gas (Hovland et al. 1997). Mud volcanoes, regardless of comparable morphology and manifestation on the Earth's surface, may be of variable origins. According to their genesis three fundamental groups are described: (1) mud volcanoes sensu stricto linked with hydrocarbon gas release (e.g. Dimitrov 2002), (2) hydrothermal mud volcanoes (e.g. Pitt and Hutchinson 1982) and (3) mud volcanoes as a manifestation of an earthquake or a sudden exogenetic event (e.g. Rogozhin et al. 2007).

Mud volcanoes sensu stricto occur mostly in areas of rapid sedimentation, lateral tectonic compression or recent magmatic activity (Milkov 2005). These mud volcanoes are often associated with hydrocarbon deposits. Gases, which are generated during hydrocarbon formation processes, and water force the mud ascent to the Earth's surface. This type of mud volcanoes occurs mostly in association with both thick sedimentary sequences, reaching several kilometres, and the existence of similarly thick layers of clay-rich sediments in deeper parts. The size of the mud volcanoes s.s. varies from small gryphons of about one meter in diameter to structures several kilometres across and with relative heights of first hundreds of metres (Dimitrov 2002; Kholodov 2002).

Mud volcanoes sensu stricto are irregularly clustered in separated areas forming belts, which coincide with active areas of the continental plate boundaries and zones of young orogenic structures (Dimitrov 2002). Most of the worldwide known mud volcanoes are located in eastern Azerbaijan and the Caspian Sea region (Panahi 2005).

Hydrothermal mud volcanoes occur in regions characterised by recent volcanic activity. Volcanic gas and hot water rising to the surface detach and entrain fine-grained particles of adjacent rocks. Cones of mud, usually no more than one or two metres in height, mud cauldrons and fumaroles are all apparent results of these geologic processes. High water temperature, formation of large volumes of water vapour and absence of hydrocarbon gases are characteristic of these mud volcanoes (Kholodov 2002). 'Mud pot' is an alternative term used for hydrothermal mud volcanoes, which are in fact recognized to be thermal springs. The best-known hydrothermal mud pots occur in Yellowstone National Park in USA (Pitt and Hutchinson 1982).

Mud volcanoes as manifestation of earthquake or sudden exogenetic events include small mud or often sand volcanoes, which arise as a subsequent effect of 
sudden events such as earthquakes or floods causing rapid increase in strain in rocks or abrupt change in piezometric pressure in aquifers. In contrast to the previous two groups of mud volcanoes, the material ejected to the surface is derived from shallow depths, usually only a few tens of metres. The height of this type of mud volcanoes reaches generally several decimetres, rarely above one meter; their diameter may attain several metres.

Most of these small mud volcanoes are directly related to earthquakes. During earthquakes, pressure of pore water increases and soils saturated with groundwater lose their shear resistance, which leads to exceeding the threshold of thixotropy. This results in liquefaction of soils and sediments. If the liquefied layer is covered by dry/more compact sediments, by impermeable layers or by frozen ground, fluidized sediments are ejected to the surface through open ruptures and form mud or sand cones. Such ejections of mud and sand on the ground surface as a result of earthquakes are called mudvolcanic manifestations (Panahi 2005) and occur mainly in the areas with no mud volcanoes sensu stricto.

Mud volcanic manifestations have accompanied several strong earthquakes with magnitudes above 7 . For example small mud mounds forming as a result of surficial effect of the 2003 Altay Earthquake $\left(M_{L}=7.5\right)$ are common in flood plains of the Chuya and ChaganUzun rivers in the Gorny Altay (Rogozhin et al. 2007). A number of small mud volcanoes appeared during the Olyutorsk Earthquake $\left(\mathrm{M}_{\mathrm{L}}=7.6\right)$ in 2006 on the Korf spit near the Kamchatka Peninsula (Pinegina and Konstantinova 2006).

\subsection{Mud volcanoes in Mongolia}

The territory of Mongolia is built by numerous geological blocks consolidated mainly during the Palaeozoic and became tectonically reactivated along the intracontinental deformation zones during the Cenozoic (Tapponier and Molnar 1979; Cunningham et al. 2003). Owing to lacking hydrocarbon occurrences, no mud volcanoes sensu stricto occur in this region.

The nearest group of mud volcanoes sensu stricto, located outside active belts, is known from the Xinjiang Uygur Autonomous Region in Northwest China (Seach 2007). Further Asian mud volcano areas are in the Central Sakhalin and Hokkaido-Sakhalin shear zones (Chigira and Tanaka 1997; Shakirov et al. 2004; Ershov and Mel'nikov 2007). These form a part of the Pacific Ocean mud volcano belt (Dimitrov 2002). The nearest mud volcano localities in the Alpine Himalayas active belt are in the Punjab region of Pakistan and India as well as in the Assam region of India (Snead 1964; Dimitrov 2002; Kholodov 2002).
Mongolian hydrothermal springs in the Khangay thermal area (Gendenjamts 2003) are developed within Cenozoic large arched uplifts. They belong to the Mongolian-Baikal hydrothermal water region (Lomonosov 1976). No hydrothermal mud volcanoes have yet been described here.

References to mudvolcanic manifestations in Mongolia are linked to strong Mongolian earthquakes on July $9^{\text {th }} 1905$ (Khangay Earthquake $M_{L}=8.4-8.7$ ) and on December $4^{\text {th }} 1957$ (Gobi-Altay Earthquake, $\mathrm{M}_{\mathrm{L}}=8.3$ ). Mud spouts are incorporated on the map of the Khangay Earthquake on the southern bank of Lake Bust Nuur in the northwest Mongolia (Voznesenskii and Dorogostaiskii 1914). Florensov and Solonenko (1963) registered clay outflows from fractures on the southern bank of Lake Orok Nuur (northern piedmont of NW Gobi Altay) related to the Gobi-Altay Earthquake. These fractures were caused by hydraulic pressure exerted on the layers of frozen ground during the earthquake in 1957. Liquefaction craters interpreted as sand blows formed during an earthquake were described from the Myanga Bulag oasis in the Biger Nuur Basin (Fig. 1) by Cunningham et al. (1996). Local people reported that the 1957 earthquake caused fountain-like ejections at Myanga Bulag oasis.

A new group of mud volcanoes was discovered during the geological survey (Hanžl and Aichler 2007) of the Zamtyn Nuruu area at junction of the Mongolian and Gobi Altay. The mud volcanoes occur in a nameless, local valley on the northern slopes of the Khar Argalantyn Nuruu Mts., $30 \mathrm{~km} \mathrm{~W}$ of Boon Tsagaan Nuur Lake. They belong to the earthquake-related type of mud volcanoes.

The spring of Dovyn Bulag is the closest feature incorporated on local topographic maps. Therefore, we name this occurrence of mud volcanoes "the Dovyn Bulag field". There are in fact four springs, two groups of mud volcanoes and one well with groundwater level near the surface. The Mongolian name "Dovyn Bulag" means in English "small hill spring". It is highly probable that the spring received its name when a cone of a mud volcano appeared.

\section{Regional geography and geology of the area}

\subsection{Geography}

The area of mud volcanoes is located in the western part of the Gobi Altay Range represented here by the Khar Argalantyn Nuruu Mts. (with the Khuren Ondor Uul summit reaching 2,724 $\mathrm{m}$ a.s.1.) as well as by the Shiliin Nuruu Highlands (Figs 1-2). The mud volcanoes are exposed on the northern foot of strongly eroded NW slopes 


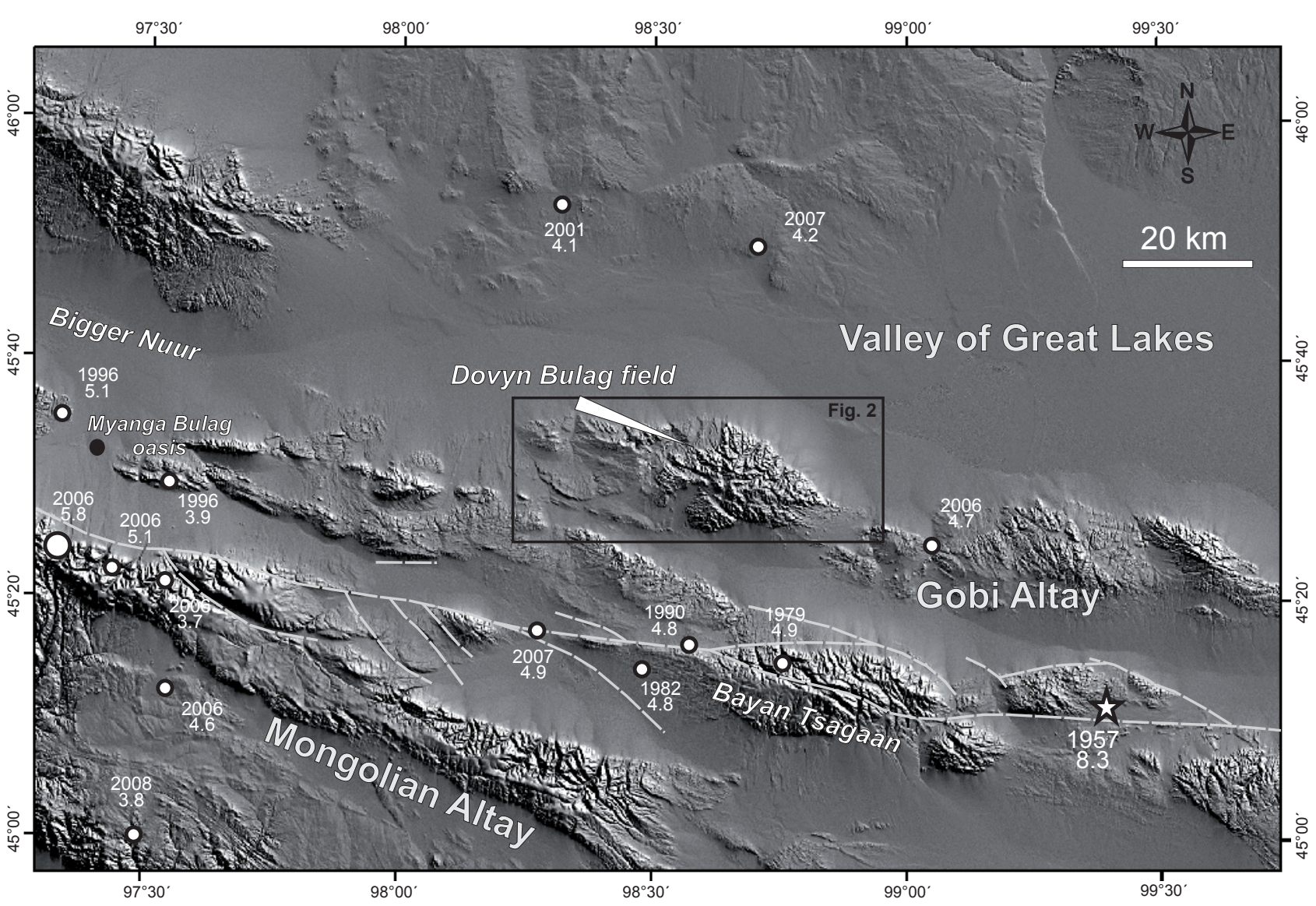

Fig. 1 Digital elevation model with positions of epicentres, years and magnitudes of earthquakes registered by NEIC (National Earthquake Information Centre, U.S. Geological Survey - NEIC 2007) since 1975 in the area of the junction of the Mongolian Altay and of the Gobi Altay. Epicentre of the Gobi Altay 1957 Earthquake is marked by star, epicentre of the Biger 2006 Earthquake by big circle, Dovyn Bulag mud volcanoes by the arrow (see also Fig. 2). Course of the western part of the Bogd fault system is marked by light grey line.

of the Khar Argalantyn Nuruu near the Dovyn Bulag spring at an altitude of $c .1,900 \mathrm{~m}$ a.s.l. The slopes are open towards the north to a wide intermountain endorheic depression of Ulaan Shalyn Khooloi, which is a part of the "Valley of Great Lakes". This inland drainage basin includes also Lake Boon Tsagaan Nuur, one of the largest Mongolian salt lakes. The region belongs to arid and semi-arid zones with the mean annual precipitation rates varying between 150 and $200 \mathrm{~mm}$. There are only valleys with periodical water streams as typical in dessert areas. The groundwater is discharged from rare springs and is infiltrated back into the valley sediment filling, usually only a few metres from the discharge sites.

\subsection{Geology}

Gobi Altay has a basin-and-range type appearance. The geomorphology throughout the region suggests Cenozoic stages of an active orogeny (Cunningham et al. 1996). The Gobi Altay range represents one of the youngest mountain ranges in Central Asia. This is consistent with the idea of a northward propagation of the transpressional deformation from the Himalayan front to the Siberian Craton (Vassallo et al. 2007). The isolated mountain massif evolved as a restraining bend along the left-lateral intracontinental $\mathrm{E}-\mathrm{W}$ trending and recently active fault (Cunningham et al. 2003). This structure (Fig. 1) is known as Bogd fault (Florensov and Solonenko 1963; Tapponier and Molnar 1979) or as North Gobi Altay fault system (Cunningham et al. 2003).

Geologically, the NW part of the Gobi Altay belongs to the Lake Zone Terrane after Badarch et al. (2002) which is composed of the Neoproterozoic to Lower Palaeozoic metamorphic and volcanosedimentary complexes. It is covered by the Lower Permian volcanic sequences and by the Upper Mesozoic continental sediments and volcanic rocks (Fig. 2) related to the western part of the Upper Mesozoic Gobi Altay rift (Yanshin 1976; Yarmolyuk 1986).

The Dovyn Bulag field with mud volcano manifestations is situated in the Quaternary infill of a small valley 


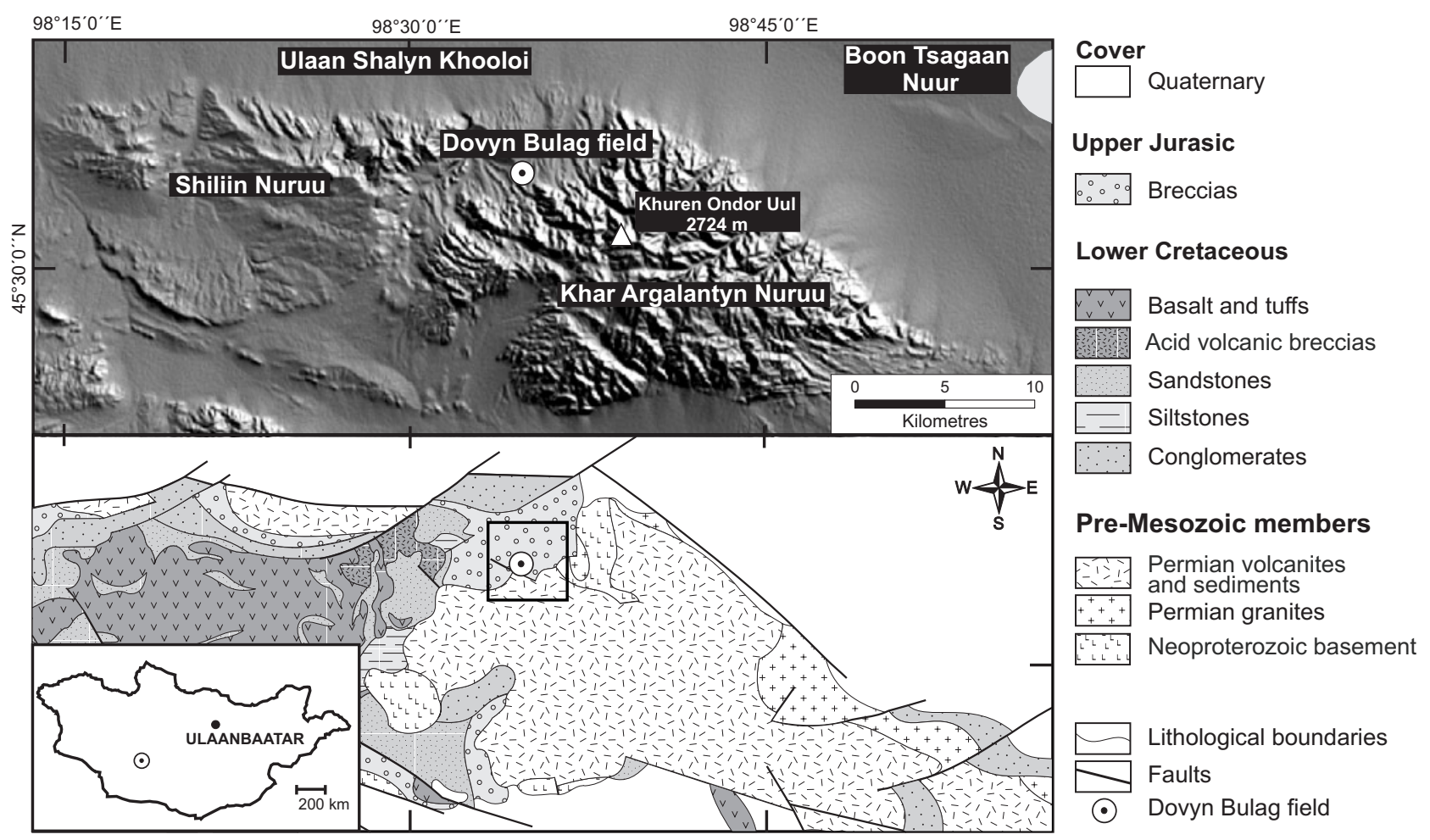

Fig. 2 Location, geomorphology and geology of the discovered Dovyn Bulag mud volcano field in the Khar Argalantyn Nuruu region, NW Gobi Altay, Mongolia.

incising into Jurassic sediments on the NW foothill of the Khar Argalantyn Mts. The basement of the Mesozoic sediments is formed here by the Neoproterozoic metabasalts and metadiorites (Khan Taishir Formation) and by Lower Permian bimodal volcanic rocks (Khar Argalantyn Formation) intruded by Permian granites (Hanžl et al. 2007).

The Mesozoic sequence is well exposed in the Shillin Nuruu syncline west of the studied locality. Sedimentation started with poorly sorted breccias and conglomerates of the Upper Jurassic age covering transgressively the pre-Mesozoic basement. The Upper Jurassic sedimentation was terminated by the Aptian-Albian volcanic activity (Buriánek et al. this volume). The gryphons of the Dovyn Bulag field are related to the lowermost sequence of the Mesozoic sediments of the Toromkhon Formation. Rauzer et al. (1987) estimated the thickness of the Jurassic Toromkhon Fm. to be of up to $650-700 \mathrm{~m}$, but in the studied area there are no outcropping sections, which would confirm a thicknesses exceeding 250-300 m. The sediments of the Toromkhon Fm. consist of poorly sorted to extremely poorly sorted conglomerates, breccias and sandy conglomerates. The occurrence of siltstone horizons within the formation is rare. Poorly sorted and subangular clasts in not graded massive conglomerates indicate rapid sedimentation under arid to semiarid conditions. The lithification of the sediments is relatively low and they are interpreted as sediments of a proximal part of alluvial fans (Gilíková et al. 2007). Four lithological members of the Lower Jurassic sediments (from bottom to the top) were distinguished in the vicinity of the Dovyn Bulag (Fig. 3):

1. poorly sorted, weakly lithified breccias to conglomerates with matrix-supported fabric, matrix being silty to sandy,

2. alternation of weakly consolidated conglomerates, with layers of sandstones, siltstones and mudstones,

3. red siltstones with nets of tiny carbonate veins,

4. red siltstones alternating with sandstone layers and red to grey silty mudstones.

The breccias are usually the lowermost member of the sequence, nevertheless the boundaries between lithologies are transitional and facies substitute each other in a finger-like manner.

Bedding is monoclinal, dipping gently to the northwest, with the dip reoriented of up to $40^{\circ}$ along the faults in vicinity of the tectonic contact with the southern Permian volcanic rocks.

Quaternary sediments are represented by Pleistocene-Holocene gravel plains covering the Mesozoic sediments. The thickness of poorly sorted, semi-angular gravels reaches up to 5 metres in the area of the Dovyn Bulag. These gravel plains are cut by valleys filled with the Holocene fluvial sediments of intermittent streams. 


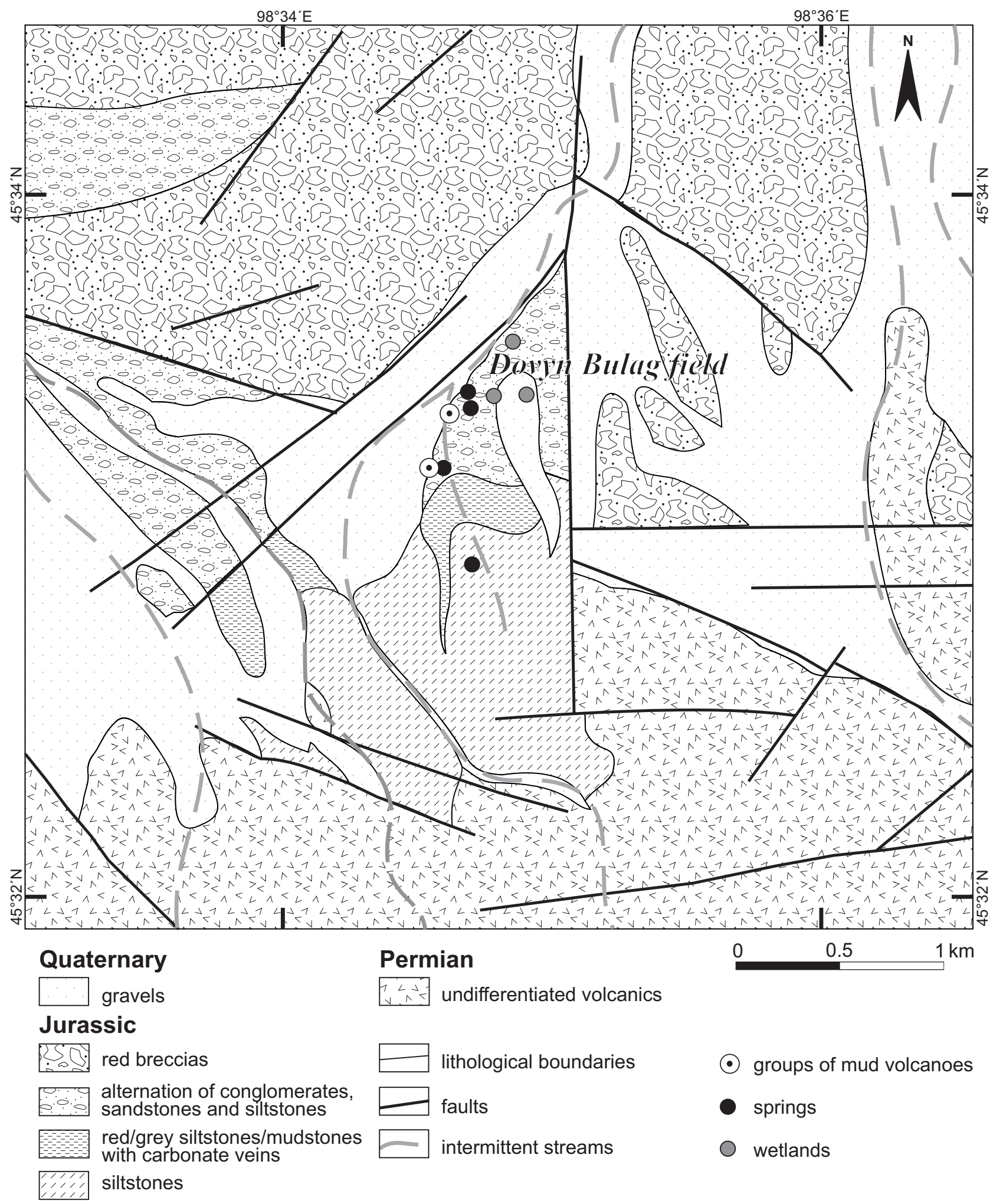

Fig. 3 Detailed geological map of the Dovyn Bulag field.

They are characterized by a large variation in grain size, from coarse-grained gravels to sands. In short, narrow valleys sands and silts dominate as the youngest fill.
In the area of the Dovyn Bulag field the pre-Mesozoic basement is represented by the Permian volcanic sequences. The transgressive basis is exposed approximately 
$1.5 \mathrm{~km}$ towards SW. The dominant part of the basement has suffered upheaval along the NNW-SSE oriented faults south of the locality (Figs 3-4). The Mesozoic sediments in the subsided area form separate blocks bound by numerous local dislocations. The Dovyn Bulag springs are situated along the northern edge of triangular block bordered by a N-S oriented fault in the east, a NW-SE oriented fault in the southwest and NE-SW oriented fault in the northwest. This block is sunken in adjacent poorly sorted Jurassic breccia sediments and represents higher members of the Jurassic sequence. Its lowest part is formed by the alternation of conglomerate benches with layers of red-brown sandstones and siltstones; the red siltstones and mudstones, which are pervaded by extensive nets of calcite veins, are exposed in the hanging wall. The uppermost member is represented by red siltstones with layers of grey mudstones. All strata are gently dipping to the NW and boundaries among them are transitional.

\section{The mud volcanoes of the Dovyn Bulag field}

\subsection{Morphology}

The mud volcanoes occur on the lower flat floor of a small valley near its opening to the larger one. The small valley is oriented $\mathrm{N}-\mathrm{S}$, being situated approximately at
$1,900 \mathrm{~m}$ a. s. 1. A flat slope composed of weathered Jurassic sediments with their tops about 5-7 $\mathrm{m}$ above the valley floor forms the right bank. The left bank is steep with the top formed by the Quaternary gravels $10-15 \mathrm{~m}$ over the floor. Benches of conglomerates are exposed in the slope and form also the footwall of the Quaternary fill of the valley. The valley is about $25 \mathrm{~m}$ wide near the mouth, then it broadens in the centre between two groups of mud spots and passes into a narrow gully towards the south. The floor of the valley is covered by a muddy crust with salt efflorescence (Fig. 5), the surface of the floor seems to be slightly domed. Mud is slightly eroded by an intermittent local stream. Sandy debris with pebbles accumulates along the banks.

Mud volcanoes form two groups, at a distance of 250 metres from each other (Fig. 3).

A northern group, downstream group occupied the right bank of the valley near its mouth. It is scattered irregularly over an area of $40 \times 15 \mathrm{~m}$. The group consists of several gryphons with a radius from first decimetres to 3 metres and an elevation up to $0.8 \mathrm{~m}$. Small pools filled with muddy water with negligible discharge and direct mud outflows from the bottom of the valley occur there, as well. The thickness of the liquid mud measured in a gryphon is $1 \mathrm{~m}$ below the surface.

A southern group of mud volcanoes forms a partly continuous mound $20 \mathrm{~m}$ long and up to $6 \mathrm{~m}$ wide. It lies on the left bank of the valley.

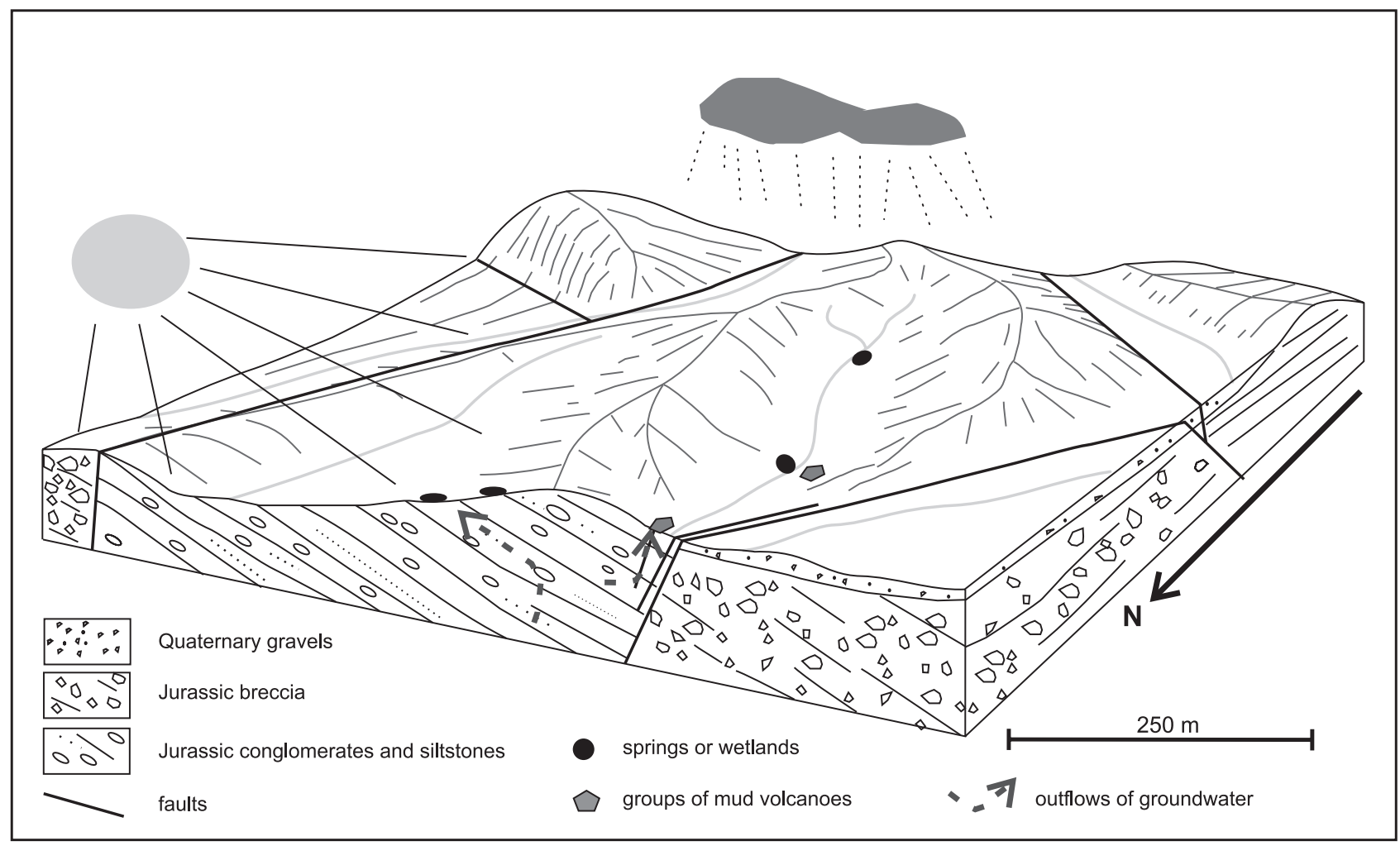

Fig. 4 Block diagram with simplified geology and geomorphology of the Dovyn Bulag field. 

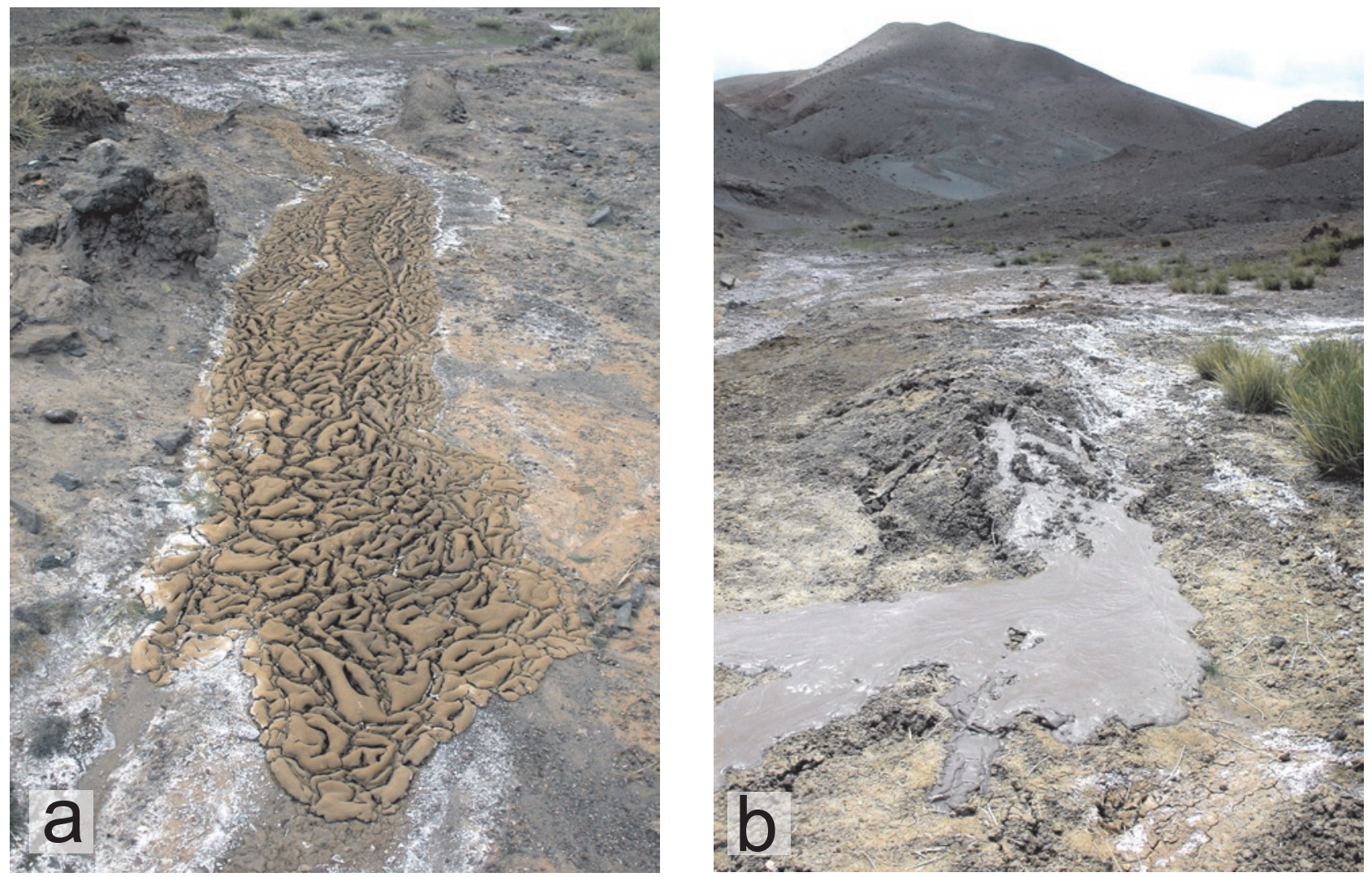

Fig. 5 Examples of mud volcanoes from the Dovyn Bulag field: a - Fresh mudflows from the northern group of the mud volcanoes, white spots on the floor are precipitated salts; $\mathbf{b}$-A mud outflow from a top of a mound (southern group of the mud volcanoes) triggered by a small artificial mechanical perturbation on the top of the mound.

At the time of our discovery of the locality in June 2006, mud volcanoes were in the passive stage without visible mud outflows. But some of gryphons were active not long before our visit, since fresh mudflows occurred in their vicinity (Fig. 5a). The equilibrium of pressure conditions in the area was labile, as even a small artificial mechanical perturbation of a top part of a mound provoked a mud outflow (Fig. 5b). Other cones were much older according to the degree of their erosion.

Brown and dark-reddish colour of mud predominated, grey mud was less frequent and it flowed out only from mud volcanoes of the southern group.

\subsection{Groundwater chemistry}

Groundwater, which seeps in the mud volcanoes and in their vicinity, has strong basic character. Field measurements of $\mathrm{pH}$ in springs, the nearest well and in pools of muddy water have shown variation from 8.3 to 9.9. The highest measured values were directly in the mud volcanoes areas. Electrical conductivity of groundwater coincides with the values measured in the surrounding parts of the Gobi Altay and of the Mongolian Altay (Rukavičková 2007). It reached values of 900-2,200 $\mu \mathrm{S}$. $\mathrm{cm}^{-1}$ corresponding to TDS (total dissolved solids) ranging from 700 to $1,700 \mathrm{mg} \cdot 1^{-1}$ according to a correlation established for this area. Groundwater sampled in a small mud water pool in northern group of mud volcanoes is of $\mathrm{Na}-\mathrm{HCO}_{3}$ type (Tab. 1). A high proportion of hydrogen carbonate among the anions, which is unusual in the surrounding area (Rukavičková 2007), is caused by locally higher content of calciferous component in clays and siltstones. The high content of $\mathrm{Na}$ is typical of groundwater in Mesozoic sediments in the Shiliin Nuruu Highlands.

According to calculation performed by PHREEQC model (Parkhurst 1995), the water is Fe oversaturated and its ferruginous precipitation causes a red colour of mud. The mud particles in the water samples contain mainly quartz and clay minerals of the smectite group (montmorillonite) with subordinate amounts of feldspars, mica (muscovite) and hematite. 
Tab. 1 Chemical analyses of groundwater from a muddy pool

\begin{tabular}{|c|c|c|c|c|c|c|c|c|c|}
\hline $\mathbf{L i}$ & $\mathrm{Na}$ & K & NH4 & Mg & Ca & Mn & $\mathrm{Fe}$ & $\mathrm{Zn}$ & Al \\
\hline$\mu \mathrm{g} .1^{-1}$ & mg..$^{-1}$ & mg..$^{-1}$ & mg..$^{-1}$ & $\operatorname{mg} .1^{-1}$ & $\mathrm{mg} . \mathrm{l}^{-1}$ & $\mu \mathrm{g} . \mathrm{l}^{-1}$ & $\mathrm{mg} . \mathrm{l}^{-1}$ & $\mu \mathrm{g} . \mathrm{l}^{-1}$ & $\mathrm{mg} . \mathrm{l}^{-1}$ \\
\hline 24 & 346 & 5.5 & $<0.02$ & 12.9 & 34.1 & 516 & 5.5 & 30 & 5.7 \\
\hline $\mathrm{Cl}$ & F & $\mathrm{NO}_{3}$ & $\mathrm{SO}_{4}$ & $\mathrm{HCO}_{3}$ & $\mathrm{SiO}_{2}$ & TDS & El. Cond. & pH & $T$ \\
\hline $\mathrm{mg} . \mathrm{l}^{-1}$ & $\mathrm{mg} . \mathrm{l}^{-1}$ & $\mathrm{mg} . \mathrm{l}^{-1}$ & $\mathrm{mg} .1^{-1}$ & $\mathrm{mg} .1^{-1}$ & $\mathrm{mg} . \mathrm{l}^{-1}$ & $\mathrm{mg} . \mathrm{l}^{-1}$ & $\mu \mathrm{S} . \mathrm{cm}^{-1}$ & & ${ }^{\circ} \mathrm{C}$ \\
\hline 47.9 & 3.2 & $<0.30$ & 212 & 641 & 34.1 & 1,349 & $1,460.0$ & 8.27 & 15 \\
\hline
\end{tabular}

\section{Origin of the Dovyn Bulag mudvolcanic manifestation}

\subsection{General conditions}

Mud volcanoes at the Dovyn Bulag field belong to the group of mud volcanoes related to seismic events. Liquefaction during, and after, an earthquake shock resulting in exceeding the threshold of thixotropy is usually the major factor triggering formation of a mud volcano of this type.

Liquefaction manifestations occur mainly in young, unconsolidated, water-saturated sediments accumulated in lowland areas near the level of regional erosion base, where large aquifers are drained. River valleys, coastal areas and lakesides in basins of inland drainage (in case of arid climate) are the places meeting the requirements for liquefaction processes.

The mud volcanoes at the Dovyn Bulag field lie on the foot of the Khar Argalantyn Nuruu Mts. in a small barren valley, which, based solely on morphologic criteria, can be a local drainage path for shallow Quaternary aquifer during rare strong rains. An episodic stream appears in this case on the bottom of the valley.

The Gobi Altay is an area with a well-documented recent seismicity (for overview see Kurushin et al. 1997; Vassallo et al. 2007). Many earthquake events with magnitudes up to 8.3 were recorded in databases of ISC (International Seismological Centre) and of NEIC (National Earthquake Information Center, U.S.A.) from this area (ISC 2007; NEIC 2007).

\subsection{Hydrogeology}

The whole area of the Khar Argalantyn Nuruu Mountains has no natural groundwater seepages. This points to the fact that shallow, near surface groundwater flow is missing here. Water from rare rains infiltrates through regolith to the zone of a subsurface fracture open system. The depth of this zone usually reaches up to $80-100 \mathrm{~m}$. Groundwater from deeper aquifers circulates into the covering sedimentary filling of adjacent basins.
There is a common drainage along a fault system, which borders the foothill of the Khar Argalantyn Nuruu Mountains. Springs associated with near-surface groundwater level frequently accompany these faults. In the springs, the groundwater has a low TDS level atypical of the conditions in the surrounding arid area (Rukavičková 2007). The low TDS levels of groundwater indicate a deeper circulation. In arid climate, a strong TDS increase occurs in groundwater in aquifers near the surface, since these layers contain soluble weathering products and evaporates. Deeper groundwater, in firm rocks with a low content of soluble salts and ascending quickly along fault to the surface, has relatively low TDS.

The mud volcanoes lie at the foot of the Khar Argalantyn Nuruu Mountains close to several faults with supposed groundwater drainage to Jurassic sediments in the subsided block, so that the sediments in the mud volcanoes vicinity are significantly saturated with groundwater.

The faults bordering this block with mud volcano manifestations inhibit the runoff of groundwater further to the centre of sedimentary basin on the eastern and northwestern sides. The faults were sealed by clay or silt components during, or gradually after, the movements and act now as hydraulic barriers. Breccias and conglomerates at the base of the sedimentary sequence form the main aquifer in the area. Alternating beds of conglomerates and sandstones (local aquifers) with layers of siltstones and mudstones (local aquitards) in the roof of the main aquifer altogether act as partial aquitard. The southern part of the subsided block is covered with an impermeable layer of red siltstones.

A single main closed and confined aquifer and a number of local confined or partly confined aquifers are the result of alternation of the impermeable and permeable beds and sealing of groundwater flow-off paths. Due to a high hydraulic gradient caused by steep morphology, piezometric levels of the aquifers are close to, or even above, the surface. High frequency of small springs, wetlands and areas with green vegetation in the mud volcanoes vicinity proves the high degree of the Jurassic sediments saturation and a small depth to the water table. This drainage occurs on the northern side of the block, 
where siltstone aquitard is lacking and groundwater slowly soaks from coarse-grained layers.

No permanent stream occurs in the mud volcanoes valley, due to arid climate. Episodic rains flush away silts and clays from the upper, steep part of the valley to the lower, flat part. This fine-grained material dries out and forms an impermeable crust covered by evaporates.

\subsection{Recent seismic activity}

Earthquake events in the Gobi Altay area are related to Cenozoic faults, which evolved in response to the collision of the Indian and Eurasian tectonic plates. The master fault system, the western prolongation of the recent active, E-W oriented Bogd fault, is situated $35 \mathrm{~km} \mathrm{SW}$ of the Dovyn Bulag field (Fig. 1). Foreberg structures described by Bayasgalan et al. (1999) at the northern foothill of the Bayan Tsagaan Mts., which were probably reactivated during the 1957 Gobi-Altay Earthquake $\left(\mathrm{M}_{\mathrm{L}}=8.3\right)$, are located even closer.

In the last ten years (1997-2007), 11 earthquakes were recorded with epicentres in a distance up to 100 kilometres from the Dovyn Bulag field according to the databases of ISC and NEIC (Fig. 1). Magnitudes of these earthquakes varied between 3.7 and 5.8 and the nearest epicentre was located $30 \mathrm{~km}$ from the studied locality. All the earthquakes were shallow, with hypocentres in depths of 10-30 km. According to Panahi (2005), solely such shallow earthquakes influence the mud volcanoes activity. Most of the epicentres concentrated in the close vicinity of the Bogd fault escarpment. However, two of them were localized north of the mud volcanoes in the Ulaan Shalyn Khooloi depression.

The mud volcanoes at the Dovyn Bulag field were discovered five days after a series of four earthquakes, recorded by the worldwide seismic network on $15^{\text {th }}$ June 2006. The earthquakes were of magnitudes 3.9-5.8 and their epicentres were near the town Biger $90 \mathrm{~km} \mathrm{SW}$ of the Dovyn Bulag (ISC 2007). Since raw mudflows (Fig. 5a) were present at the locality, it is obvious that the last period of mud volcanoes activity was related to these earthquakes. The strongest earthquake in June 2006 was the second largest occurring in the area after the major seismic event in December $1957\left(\mathrm{M}_{\mathrm{L}}=8.3\right)$ and its aftershocks in 1958. The epicentre of this Gobi-Altay 1957 Earthquake was localised $75 \mathrm{~km}$ E of the Dovyn Bulag field (Fig. 1).

\section{Discussion}

Mudvolcanic manifestations and liquefaction are produced mainly by strong earthquakes. Panahi (2005) reported that mudvolcanic manifestations accompany earthquakes of magnitude $M_{L}>5.4$. According to Ambraseys (1988), liquefaction can occur for earthquakes with magnitudes as low as $c$. 5, however, magnitudes of c. 5.5 to 6 are the lower limit at which the liquefaction effect becomes relatively common. All available references about mudvolcanic manifestations from the Mongolian or from Russian parts of the Altay Mts. are related to earthquakes with magnitudes greater than 7 . The Biger Earthquake (June 15 $5^{\text {th }}$ 2006) with magnitude 5.8 took place near the lower limit for mudvolcanic manifestation. Wang at al. (2006) evaluated worldwide data for earthquakes related to liquefaction occurrence and established a simple equation for liquefaction limit $R_{\max }(\mathrm{m})$ that represents the distance from the epicentre of a given magnitude $M$, beyond which the liquefaction is not observed:

$$
\log R_{\max }=2.05( \pm 0.10)+0.45 \mathrm{M}
$$

According to this equation, the Biger Earthquake with magnitude 5.8 could have provoked liquefaction only in a distance up to $45 \mathrm{~km}$. The Dovyn Bulag field is located $90 \mathrm{~km}$ from the epicentre of the Biger Earthquake; nevertheless active mud volcanoes with a provable relation to this earthquake occur here.

The mud volcano area of the Dovyn Bulag field with its principal vents was formed probably during the GobiAltay Earthquake in 1957. The earthquake intensity and the distance from the epicentre were sufficient for mudvolcanic (liquefaction) manifestation. During worldwide earthquakes with magnitude above 7.5 , ejection of fluidized sediments occurred at distances of hundreds of kilometres from the epicentres (Rajendran et al. 2001).

The subsided block with Dovyn Bulag mud volcanoes forms a closed "basin" with confined groundwater surface. Additionally, high aquifer pore pressure increased during 1957 earthquake led to hydraulic fracturing and to opening of current fractures in the weakest part of the upper aquitard. Water, which flowed up during aquifer pressure compensation, entrained liquefied mud and first cones of mud arose on the earth surface. Fault permeability changes and increases in water discharges in springs are commonly observed after strong earthquakes (Rojstaczer and Wolf 1992; Montgomery and Manga 2003).

The groundwater level in the main and local aquifers is confined due to the permanent high hydraulic gradient and the equilibrium of pressure condition in the area is metastable. A small pressure impulse (increase of aquifer pressure) would be sufficient to exceed the threshold of thixotropy and could induce a mud and water ejection through conduits predisposed by the Gobi-Altay Earthquake. Even a weak or distant earthquake or an increase in piezometric level due to a high precipitation amount could be the decisive impulse. 
Clay and silt particles are often bound by precipitated salts due to the arid climate. The salts are leached during water level increases and the sediments become susceptible to liquefaction. A relatively high content of smectites in mud may result in a significant role for swelling. We suppose that the stress caused by the increase in volume of sediments during their saturation is released by a mud outflow.

Preservation of mud cones in various stages of weathering and also the local name of the locality bear an evidence for repetitious activity of mud volcanoes at the Dovyn Bulag field.

\section{Conclusions}

A group of small mud volcanoes was discovered during a geological survey of the NW Gobi Altay in June 2006. The origin of mud volcanoes is closely associated with the recent seismic activity in the area. They arose probably during Gobi-Altay Earthquake in 1957.

If an earthquake shock encounters the sedimentologic, climatic and hydrogeologic prerequisites such as water saturated, unconsolidated sediments tending to a thixotropic behaviour in a closed, confined aquifer, then even weak or far earthquake could initialize the mudvolcanic manifestation. Such conditions concur at the Dovyn Bulag field and enable the mud cone rise.

The equilibrium between the force acting upwards (piezometric pressure, rock strain) and the resistance of sediments is labile. During an earthquake, this equilibrium is disturbed and a short active life period of mud volcanoes may start. We suppose that extreme hydrological events as long-lasting rains can distinctly increase piezometric level in aquifers and break the equilibrium in a manner similar to the earthquake.

Episodic activity of the mud volcanoes is manifested by formation of new mud cones and outflows. Old cones gradually vanish by erosion. The Dovyn Bulag field is a model example of repeated geological manifestation of earthquakes. Hence, the occurrences of mud volcanoes can be used to detect recent seismicity or palaeoseismicity in a particular area.

Acknowledgements. The fieldwork was carried out during the project Geological survey of the Mongolian Altay at the scale of 1:50 000 undertaken in the frame of the Program of the Development Assistance Project of the Czech Republic. We are grateful to the staff of the expedition, above all to excellent Mongolian drivers. We thank to F.H. Weinlich, S. Vrána, L. Kraftová, T. Pačes and K. Young for critical reading and help in improving the manuscript.

\section{References}

Ambraseys NN (1988) Engineering seismology. Earthq Eng Struct Dyn 17: 1-105

Badarch G, Cunningham WD, WindLey BF (2002)A new subdivision for Mongolia: implications for Phanerozoic crustal growth in Central Asia. J Asian Earth Sci 21: 87-110

Bayasgalan A, Jackson J, Ritz JF, CArretier S (1999) Forebergs, flower structures, and the development of large intra-continental strike-slip faults: the Gurvan Bogd fault system in Mongolia. J Struct Geol 21: 1285-1302

Buriánek D, Hanžl P, Bolormaa K, Erban V (2008) The early Cretaceous volcanic activity in the western part of the Gobi-Altay rift (Shiliin Nuruu, Mongolia). J Geosci 53: $167-180$

Chigira M, TANAKA K (1997) Structural features and the history of mud volcanoes in southern Hokkaido, northern Japan. J Geol Soc Japan 103: 781-791

Cunningham WD, Widley BF, DorjnamuaA D, BadamgaROV J, SAADAR M (1996) Late Cenozoic transpression in southwestern Mongolia and the Gobi Altai-Tien Shan connection. Earth Planet Sci Lett 140: 67-81

Cunningham WD, Dijkstra A, Howard J, Quarles A, BADARCH G (2003) Active intraplate strike-slip faulting and transpressional uplift in the Mongolian Altai. In: Storti F, Holdsworth RE, Salvini F (eds) Intraplate Strike-Slip Deformation Belts. Geol Soc London Spec Pub 210: pp 65-87

Dimitrov LI (2002) Mud volcanoes - the most important pathway for degassing deeply buried sediments. Earth Sci Rev 59: 49-76

ERshov VV, Melnikov OA (2007) Unusual eruption of the main Pugachevo gas-water-lithoclastic (mud) volcano in Sakhalin during the winter of 2005. Russ J Pac Geol 1: 366-370

FLoREnSov NA, SolonenKo VP (eds) (1963) The Gobi-Altay Earthquake. Akad Nauk USSR, Moscow, pp 1-394 (in Russian)

Gendenjamts O (2003) Interpretation of geochemical composition of geothermal fluids from Árskógsströnd, Dalvík, and Hrísey, N-Iceland and in the Khangai area, Mongolia. Geothermal Training Programme, Reykjavík, Reports 10: 219-252

Gilíková H, Budil P, Otava J, HanžL P, Buriánek D (2007) Mesozoic. In: HanžL P, Aichler J (eds) Geological survey of the Mongolian Altay at a scale of 1: 50,000 (Zamtyn Nuuu - 50), MS. Czech Geological Survey, Prague, MRPAM, Ulaanbaatar, pp 141-159

HANŽL P, Aichler J (eds) (2007) Geological survey of the Mongolian Altay at a scale of 1: 50,000 (Zamtyn Nuruu - 50), Final report. Czech Geological Survey, Prague, pp 1-377 
Hanžl P, Buriánek D, HrdličKová K, Aichler J, Gerdes A, Byambasuren D (2007) Granite massifs in the Zamtyn Nuruu area, SW Mongolia. In: BreITER K (ed) Proceedings of the $3^{\text {rd }}$ Meeting of the Czech Geological Society, Volary, 19-22 September 2007, pp 27 (in Czech)

Hovland M, Hill A, Stokes D (1997) The structure and geomorphology of the Dashgil mud volcano, Azerbaijan. Geomorphology 12: 24-37

ISC on-line data base, Bulletin 2007. http://www.isc.ac.uk, International Seismological Centre, Thatcham, United Kingdom.

Kholodov VN (2002) Mud volcanoes, their distribution regularities and genesis: communication 1. Mud volcanic provinces and morphology of mud volcanoes. Lithol Miner Res 37: 197-209

Kurushin RA, Bayasgalan A, Lziybat M, Enhtuvshin B, Molnar P, Bayarsayhan C, Hudnut KW, Lin J (1997) The surface rupture of the 1957 Gobi-Altay, Mongolia, earthquake. Geol Soc Am Spec Pap 320: pp 1-143

Lomonosov IS, Pissaesky BI, Khilko SD (1976) The role of neotectonics in the formation of the thermal springs of the Mongolian-Baikal orogenic belt. In: RónAI A (ed) Hydrogeology of Great Sedimentary Basins: Proceedings of an International Hydrogeological Conference IAH-IAHS, Budapest 1976, pp 663-670

Milkov AV (2005) Global distribution of mud volcanoes and their significance in petroleum exploration as source of methane in the atmosphere and hydrosphere as geohazard. In: Martinelli G, Panahi B (eds) Mud Volcanoes, Geodynamics and Seismicity. NATO Sci Ser 51, Springer, Amsterdam, pp 29-34

Montgomery DR, Manga M (2003) Streamflow and water well responses to earthquakes. Science 300: 2047-2049

NEIC 2007. Earthquake database. http://neic.usgs.gov/, National Earthquake Information Center, Denver, USA

PANAHI B (2005) Mud volcanism, geodynamics and seismicity ofAzerbaijan and the Caspian Sea region. In: MARTinELli G, PANAHI B (eds) Mud Volcanoes, Geodynamics and Seismicity. NATO Sci Ser 51, Springer, Amsterdam, pp 89-104

PARkhhurst DL (1995) User's guide to PHREEQC - a computer program for speciation, reaction-path, advective transport and inverse geochemical calculations. U.S. Geological Survey, Water-Resources Investigations Report 95-4227, Lakewood, Colorado

Pinegina TK, Konstantinova TG (2006) Macroseismic observation of consequences from April 21, 2006 "Olytorskoe" Earthquake. Vestn KRAUNC, Ser Nauki Zemle 1: 169-173 (in Russian)

Pitt AM, Hutchinson RA (1982) Hydrothermal changes related to earthquake activity at Mud Volcano, Yellowstone National Park, Wyoming. J Geophys Res 87(B4): 2762-2766
Rajendran K, Rajendran CP, Thakkar M, Tuttle MP (2001) The 2001 Kutch (Bhuj) Earthquake: coseismic surface features and their significance, Curr Sci 80: 1397-1405

Rauzer AA, Zhanchiv DI, Golyakov VI, Ykhina IF, Ivanov IG, Tsukernik AB, Afonin VV, Smirnov IG, Bykhover VI, Kravtsev AV, BaAtarkhuyag A, Skoryukin MI, Khodikov IV, Mantsev NV, Okaemov SV, Mischin VA, ENKHSAJKHAN T (1987) Report on results of geological survey at a scale of 1: 200,000, performed in southeast part of the Mongolian Altay, Mongolian National Republic in 1983-1986. Tekhnoexport, Moscow, pp 1-352 (in Russian)

Rogozhin EA, OvSYuCHENKo AN, MARAKHOv AV, Ushanova EA (2007) Tectonic setting and geological manifestations of the 2003 Altai Earthquake. Geotectonics 41: 87-104

Rojstaczer S, Wolf S (1992) Permeability changes associated with large earthquakes: an example from Loma Prieta, California. Geology 20: 211-214

RukavičKová L (2007) Hydrogeology. In: HanžL P, Aichler J (eds) Geological survey of the Mongolian Altay at a scale of 1: 50,000 (Zamtyn Nuruu - 50), Final report. Czech Geological Survey, Prague, pp 240-266

SEACH J (2007) Baiyanggou Mud Volcanoes. Volcano Live website, http://www.volcanolive.com/baiyanggou.html

Shakirov R, Obzhirov A, Sueze E, Salyuk A, Biebow N (2004) Mud volcanoes and gas vents in the Okhotsk Sea area. Geo-Mar Lett 24: 140-149

SNEAD RE (1964) Active mud volcanoes of Baluchistan, West Pakistan. Geogr Rev 54: 546-560

TAPPONIER P, Molnar P (1979) Active faulting and Cenozoic tectonics of the Tien Shan, Mongolia and Baykal region. J Geophys Res 84(B7): 3425-3459

Vassallo R, Ritz JF, Braucher R, Jolivet M, Carretier S, Larroque C, Chauvet A, Sue C, Todbileg M, Bourles DL, Arzhannikova A, Arzhannikova S (2007) Transpressional tectonics and stream terraces of the Gobi-Altay, Mongolia. Tectonics 26, DOI 10.1029/2006TC002081

VoznesenskiI A, Dorogostaiski V (1914) The map of the $9^{\text {th }}$ and $23^{\text {rd }}$ July 1905 earthquake area. In: Florensov NA, SolONENKo VP (eds) (1963) The Gobi-Altay Earthquake. Akad Nauk USSR, Moscow (in Russian)

Wang CI, Wong A., Dreger DS, Manga M (2006) Liquefaction limit during earthquakes and underground explosions: implications on ground-motion attenuation. Bull Seismol Soc Am 96: 355-363

Yanshin AL (1976) Map of Mesozoic and CenozoicTectonics of the Mongolian People's Republic: 4 sheets, scale 1:1,500,000. Akad Nauk USSR, Moscow

YARMOLYUK VV (1986) The structural position of continental rift zones of Mongolia. Izv Akad Nauk SSSR, Ser Geol 9: 3-12 (in Russian) 